\title{
Does Problem-Based Learning Enhances Metacognitive Awareness of Economics Students?
}

\author{
Cipto Wardoyo ${ }^{1 *}$, Bagus Shandy Narmaditya ${ }^{2}$, Agus Wibowo ${ }^{3}$ \\ 1,2Faculty of Economics, Universitas Negeri Malang, Jalan Semarang 5 Malang 65145 Indonesia \\ ${ }^{3}$ Faculty of Economics, Universitas Negeri Jakarta, Jalan Rawamangun Muka, Jakarta, Indonesia
}

\begin{abstract}
This study highlights the importance of metacognitive awareness of economics students and examines the relationship between Problem-Based Learning (PBL) and Metacognitive awareness among economics students. This research was conducted in the Faculty of Economics, Universitas Negeri Malang of Indonesia by employing economics students as the subject of the research. This study followed a classroom action research conducting in two cycles. Each cycle consists of four steps, namely planning, implementing, observing, and reflecting iteratively. The data were obtained adapted from the Metacognitive Awareness Inventory (MAI) instrument in order to understand the level of students' metacognitive awareness. The findings indicate that the level of students' metacognitive awareness is various and generally in the moderate category. After the implementation of problem-based learning, numerous students have moved to a greater level of metacognitive awareness. In this study, the noticeable changes were provided in three knowledge, including declarative, procedural, and conditional knowledge, while the lowest score was in debugging strategy. Lastly, having better metacognitive awareness helps students to overcome difficulties in economics topics.
\end{abstract}

Keywords: Problem-based learning, economics students, classroom Research, metacognitive awareness

\section{INTRODUCTION}

Metacognitive awareness plays an essential role in the success and failure of learning goals (Delahajj \& van Dam, 2016). The fundamental rationale is that metacognitive awareness helps students being capable of providing the plan, manage, evaluate, and involve in the learning and teaching process (Abdellah, 2015). The term of metacognitive was initiated by Flavell (1976), and it has gained attention for many scholars in the educational research (e.g., Asy'ari \& Ikhsan, 2019; Harrison \& Vallin, 2018; Wang \& Treffers-Daller, 2017, Mirici, 2019). Flavell (1976) defined metacognitive as knowledge and cognition about phenomena or, in other words, metacognitive is thinking about thinking. Furthermore, Schraw and Moshman (1995) pointed out that metacognitive refers to one's ability to understand and regulate cognitive processes.

Metacognitive awareness allows students to learn effectively (Darjito, 2019). It is understandable because metacognitive awareness is highly acquaintance with students' activities such as monitoring, evaluating, and reflecting in their learning process. Furthermore, it also stimulates students to learn independently and confidently (Fritzsche et al., 2018). In general, students' metacognition is related to the dimension of thinking, namely self-awareness of cognition and self-regulation of cognition (Wibowo et al., 2018). Cognition is a mental process or representation that manifests something in themselves selves, such as problem-solving, knowledge memory, and reasoning (Shahbari et al., 2014). Besides, Ridley et al. (1992) explained that metacognition as a person's knowledge of the cognitive system, individual's thinking about the thinking and essential skills in learning to learn. Further, it can be stated about two components included in metacognition, namely what individual know or do not know, and regulation of how students learn.

Anderson and Kathwohl (2001) remarked that metacognitive refers to knowledge about cognition, which generally points out to individual awareness and understanding of cognition. Metacognition plays an essential role in managing and controlling an individual's cognitive processes in studying and thinking (Papleontiou-Louca, 2003). Furthermore, having a good awareness of metacognition will lead to reaching the learning process more effective and efficient. Metacognition is essential in studying that promotes more exceptional achievement in students' academic (Daniel, 2010). Learners who can use their metacognition appropriately tend to have better achievement due to the metacognition evolves more exceptional their cognitive activities (Efrilla et al., 2018). Therefore, students' metacognitive awareness will also help students overcome issues in economics courses.

Corresponding Author e-mail: cipto.wardoyo.fe@um.ac.id https://orcid.org/0000-0002-8319-1716

How to cite this article: Wardoyo C, Narmaditya BS, Wibowo A, (2021). Does Problem-Based Learning Enhances Metacognitive Awareness of Economics Students?. Pegem Journal of Education and Instruction, Vol. 11, No. 4, 2021, 329-336

Source of support: Nil

Conflict of interest: None.

DOI: $10.47750 /$ pegegog.11.04.32

Received: 26.07 .2021

Accepted: 23.09 .2021

Publication: 01.10 .2021 
Several prior works of literature have documented the causality between metacognitive awareness and students' performance. For instance, Countinho (2007); Muhlisin et al. (2018) confirmed a positive relationship between students' metacognitive awareness and academic accomplishment. Additionally, Joseph (2009); Heswandi et al. (2015) showed that metacognition awareness in schools has not yet developed in internalizing their learning strategies, such as linking prior knowledge with new knowledge, planning, monitoring and evaluating. Consequently, it has an impact on student learning outcomes that are relatively insufficient. In addition, Young and Fry (2008); Al-Awdah, Jasmeen and Alexander (2017) pointed out that the insufficient of students' metacognitive awareness is often associated with the less attention of students' problem-solving processes. One important aspect of the problem-solving process is metacognitive awareness. Indeed, Atmatzidou, Demetriadis and Nika (2018) confirmed that cognition is essential for student learning because it influences how students apply what they have learned to address the given problems.

In economics subjects, several materials are challenging to be achieved by university students, such as materials related to the capital market, monetary transmission, aggregate demand and supply, and market forces. In this case, the lecturer or teacher should creatively provide the teaching and learning activities to reach the learning goals. Wulandari and Narmaditya (2017) attempted to apply the reader's theater model as an effort to overcome students' difficulties on the topic of unemployment and national income. Their findings suggested that implementing various methods in economics can improve student activities. Moreover, Narmaditya et al. (2018) implemented a problem-based learning model in microeconomics subject to diminish students distinguishes related to market forces of supply and demand.

In acquaintance with metacognitive awareness, problembased learning is reported as an appropriate method for students to enhance their higher thinking skills (Orozco \& Yangco 2016; Vidergor \& Gottlieb 2015). The underlying reason is that problem-based learning presents students to develop their ability to think critically toward the problems (Narmaditya et al., 2018) and potentially increase metacognitive knowledge (Herlanti et al., 2017). Problembased learning is a learning model focusing on how students face their own problems in life (Sugeng \& Suryani, 2020). In the learning and teaching process using problem-based learning, students enable to collect information, analyze the problems, and propose the solution. Moreover, this learning model evolves from the real problem that usually occurs in students' circumstances (Sugiman et al., 2019).

Problem-based learning has several characteristics in the teaching and learning process. First at all, students could provide their own critical issues in a particular subject. The learning strategy applied is open-ended, it means that after the teaching and learning process was over in a classroom meeting, it has an opportunity for learners to continue their problem not restricted based on classroom meetings (Ceker \& Ozdamli, 2016; Klegeris \& Hurren, 2011). Furthermore, the lecturer or teacher acts a role as a facilitator, and the teaching process focuses on students' activities. From the explanation, it can be concluded that problem-based learning proposes a learning model that focuses on not only the learning result but also on the learning process. The success in the learning process will lead to greater metacognitive awareness (Pantiwati \& Husamah, 2017).

Problem-based learning presents authentic and meaningful problem situations to foster student curiosity to conduct investigations and inquiries (Siagan et al., 2019). In this approach, students are engaged in solving problems through several stages of the scientific method by carrying out investigations (Phungsuk et al., 2017). Problem-based learning also provides opportunities for students to question existing phenomena and actively build understanding of concepts, including in economics in a more coherent, flexible, and systematic manner (Narmaditya et al., 2018). This is in accordance previous study by Keegan et al. (2017) which noted that problem-based learning is a model that engages students to address issues through the stages of the scientific method so that students can learn knowledge related to existing problems. At the same time, it has the skills to deal with problems that is expected can improve student learning outcomes. In this case, the teacher's role as a facilitator provides interesting teaching that helps students solve problems (Sugeng \& Suryani, 2020).

As with pedagogical innovations in general, problem-based learning is not developed based on learning or psychological theory. The problem-based learning process includes the engagement of metacognition and self-regulation known as a progressive and learner-centered active learning approach where unstructured problems are used as a starting point and end during the learning process (Yuan et al., 2020; Hardiyanti, 2018). According to Anderson (2012), metacognitive is knowledge about cognition in general and awareness of, as well as knowledge about, one's own cognition. To gain skills in problem solving, students are expected to understand the process of solving these problems and become skilled in selecting and identifying relevant conditions and concepts, looking for generalizations, formulating settlement plans and organizing what they have previously (Atmatzidou et al., 2018). Metacognitive will also encourage students' ability to overcome problems and develop higher thinking skills (Bachri \& Corebima, 2018; Narmaditya et al., 2018).

Noticeable scholars have documented the importance of encouraging metacognitive awareness (Abdellah, 2015; Jaleel \& Premachandran, 2016; Farahian \& Avarzamani, 2018; Wolfe \& Williams, 2018; Hidayat et al., 2018; Nurajizah et al., 
2018). Abdellah (2015); Hidayat et al., (2018) remarked that metacognitive awareness effectively impacts on academic achievement. Also, Jaleel and Premachandran (2016) revealed that metacognitive awareness reflects on students' understanding of the particular subject and helps students to develop their awareness. Nurajizah et al. (2018) remarked that learning science is not just about facts, concepts, or principles but also a learning process for students in everyday life. Thayeb and Putri (2017) suggested that an improvement in metacognitive awareness of students is caused by an implementing learning method that encourages students' activity, and the teacher plays a role as a facilitator.

Surprisingly, very little attention has been paid toward metacognitive awareness in social sciences, particularly in economics, and attempts to improve undergoing various methods in teaching and learning. In fact, numerous previous studies related to students' metacognitive awareness have examined many other subjects such as biology class, mathematics, chemistry, and physics (Kesici et al., 2011; Tosun \& Senocak, 2013; Arifin \& Saenab, 2014; Bogdanović et al., 2015; Gholami et al., 2016; Tibrani, 2017; Herlanti et al., 2017; Nurajizah et al., 2018). Therefore, this study presents some critical insights in understanding the metacognitive awareness of economics students and how to improve their metacognitive awareness using an appropriate method such as problem-based Learning. This study focuses on how problem-based learning can enhance the economics students' metacognitive awareness, primarily problem-solving activities that being essential of the method.

\section{Method}

\section{Research Design}

This study applied classroom action research, which is intended to provide some insights into metacognitive awareness of economics students by implementing problem-based learning (PBL). This paper was conducted in two cycles, including planning, implementing, observing, and reflecting, iteratively.

\section{Population and Sample/ Study Group/Participants}

This research was provided using Zoom meeting in two microeconomics classes in an undergraduate program

Table 1. Interval and Category of Students' Metacognitive Awareness.

\begin{tabular}{lll}
\hline Criteria & Interval Range & Category \\
\hline $\mathrm{MI}+1.5 \mathrm{SDI} \leq \mathrm{MA}$ & $234 \leq \mathrm{MA}$ & Excellent \\
$\mathrm{MI}+0.5 \mathrm{SDI} \leq \mathrm{MA}<\mathrm{MI}+1.5 \mathrm{SDI}$ & $182 \leq \mathrm{MA}<234$ & Good \\
$\mathrm{MI}-0.5 \mathrm{SDI} \leq \mathrm{MA}<\mathrm{MI}+0.5 \mathrm{SDI}$ & $130 \leq \mathrm{MA}<182$ & Moderate \\
$\mathrm{MI}-1.5 \mathrm{SDI} \leq \mathrm{MA}<\mathrm{MI}-0.5 \mathrm{SDI}$ & $78 \leq \mathrm{MA}<130$ & Fair \\
$\mathrm{MA}<\mathrm{MI}-1.5 \mathrm{SDI}$ & $\mathrm{MA}<78$ & Poor
\end{tabular}

Note: $\mathrm{MI}=1 / 2$ (highest score + lowest score), SDI $1 / 2$ (highest score + lowest score) consisting of approximately 24 students of each online class. The classes were selected considering the accumulative of previous accomplishment that seems indifferences. The sample participants for this research were chosen from classes that seemed to follow a convenient sampling technique. The material selected is related to market forces of supply and demand. The market forces of supply and demand material mainly deal with what factors affecting the increase and decrease in the market and how the market interact. Furthermore, this topic also engages on factors and issues affecting the shifting and movement along the supply and demand curve. Ideally, to understand this course, students should have a tremendous analytic and critical thinking process combined with relevant information.

\section{Instrument Development and Data Analysis}

The data were conducted using in-depth interviews, observation sheets, and semi-structured questions. To measure metacognitive awareness, we adopted Metacognitive Awareness Inventory (MAI) instrument by Schraw and Dennison (1994). The instruments were translated from English to Bahasa Indonesia. The instrument for characterizing students' metacognitive knowledge was validated by two senior colleagues. The metacognitive knowledge instrument was also empirically validated by involving 30 economic students as respondents. The statistical estimation for reliability of the items indicated acceptable with Cronbach's alpha ranges from 0.751 to 0.862 ( $>0.6$ ). In more precise, MAI measures metacognitive awareness consisting of 52 item statements, which divided into eight indicators, namely declarative knowledge, procedural knowledge, conditional knowledge, planning, information management strategy, monitoring, debugging strategy, and evaluation. Simple descriptive analysis with percentages was applied to estimate the economic students' responses to the closed-ended questionnaire, while the qualitative data was estimated undergoing conventional content analysis. In detail, the students' level of metacognitive awareness is measured by using the following formula.

\section{FINDINGS}

This study conducted in undergraduate students for microeconomics classes using problem-based learning. This method focuses on problems carried out related topics of supply and demand in economics. Students' learning activities are designed based on problem-based learning characteristics that are reflected in the learning steps according to the observation sheet, all students do the learning activities correctly. The problem as the main focus of learning is presented in the form of discourse. The discourse is listed in the student worksheet and is accompanied by procedural questions that guide students to solve problems. 
Table 2: Metacognitive Awareness of Students

\begin{tabular}{llll}
\hline & & \multicolumn{2}{c}{ Percentages } \\
\cline { 3 - 4 } No & Criteria & 1st Cycle & 2nd Cycle \\
\hline 1. & Excellent & $0 \%$ & $0 \%$ \\
2. & Good & $8.4 \%$ & $29.1 \%$ \\
3. & Moderate & $58.3 \%$ & $62.5 \%$ \\
4. & Fair & $33.3 \%$ & $8.4 \%$ \\
5. & Poor & $0 \%$ & $0 \%$ \\
\hline
\end{tabular}

Students were provided issues in supply and demand and be accomplished by several procedural statements which guiding students to overcome the issues of the courses. For instance, students have received a problem about the presence of music download in the internet toward supply and demand of Compact Disc, iPod, Music Player, and so forth. In the first meeting in first cycle, students were given numerous questionnaires from MAI. In more detail, the students' metacognitive awareness for each cycle after problem-based learning implemented was provided in table 2 .

Table 2 provides information about a comparison between metacognitive awareness of students during the cycles. Overall, the metacognitive awareness of students experienced an upward trend. In more detail, in the first cycle, it was about 33.3 percent of students were in the fair category and it declined to the level of 8.4 percent in the next cycle. The other findings showed that in the beginning, about 58.3 percent of students were categorized as moderate awareness in their metacognitive and rose slightly by approximately four percent in the next cycle. Lastly, a remarkably inclining showed in the category good awareness which is about 8.4 percent and 29.1 percent respectively from the first cycle and second cycle. Furthermore, in more precisely, students' achievement toward metacognitive awareness is presented in Table 3.

Table 3 informs the result of students' metacognitive awareness achievement. In general, it showed an increase between cycles for all indicators of metacognitive awareness after problem-based learning implemented. In more detail, the students' metacognitive awareness was in the moderate category. Compared to the situation before problem-based learning implemented, the lowest indicator was in evaluation knowledge, while the highest score was in monitoring skills. However, a significant incline existed in three knowledge including declarative, procedural and conditional knowledge. The relationship between problem-based learning and metacognitive awareness is reflected in the differences in each indicator.

\section{Discussion}

First at all, declarative knowledge of students has risen from the first cycle to the second cycle. Declarative knowledge is factual information known by students. In the beginning, it
Table 3. Achievement Indicators of Students' Metacognitive Awareness

\begin{tabular}{llll}
\hline No & Indicators & 1st Cycle & 2nd Cycle \\
\hline 1. & Declarative Knowledge & $60.2 \%$ & $73.6 \%$ \\
2. & Procedural Knowledge & $58.6 \%$ & $72.1 \%$ \\
3. & Conditional Knowledge & $60.2 \%$ & $74.6 \%$ \\
4. & Planning & $59.1 \%$ & $68.2 \%$ \\
5. & Information Management & $59.6 \%$ & $69.7 \%$ \\
& Strategies & & \\
6. & Monitoring & $61.5 \%$ & $70.3 \%$ \\
7. & Debugging Strategy & $61.1 \%$ & $65.4 \%$ \\
8. & Evaluation & $62.8 \%$ & $69.5 \%$ \\
Average & & $60.38 \%$ & $70.42 \%$ \\
\hline
\end{tabular}

was slightly higher than 60 percent and rose to the level of 73.6 percent. In the first meeting, some students suffer difficulties in finding keywords for the topic and encouraging specific ideas for given problems. An increase in the more excellent score in the second cycle implies that students have an ability to understand available information in supply and demand. They could present factors affecting supply and demand. Furthermore, in problem-based learning, students were stimulated to propose a conclusion based on objective facts, developing arguments, and communicating their findings creatively (Surif et al., 2012). Similarly, Tosun and Senocak (2013) revealed that declarative knowledge has a significant effect after the implementation of problem-based learning. The increase in declarative indicators after being given the problem-based learning model is because at the beginning of learning students are given a problem in the form of discourse in daily life, and then students identify the problem, therefore students can find out their strengths and weaknesses and know what needs to be mastered (Pradjono \& Wardana, 2009).

Procedural knowledge of students experienced an inclining trend. It was under 59 percent in the first cycle, and it rose moderately to about 72.1 percent. In the first cycle, students failed in proposing their metacognitive procedural. They succeed in presenting steps in general, however, they cannot illustrate more detailed instructions. For instance, it happened when students obtained a case study related to a declining number of workers in a company toward supply and demand. It implies a better performance after Problem Based Learning applied in the classroom. This movement was caused by instructions from the lecturer to follow the procedures comprehensively to address the given problems in supply and demand. Sawhey (2015) mentioned that in procedural knowledge, that is knowledge about how to apply learning procedures, for example, students are required to use strategies to find out the learning process, and when to apply processes in various situations students can also gain knowledge undergoing cooperative learning, and solving the problem. 
Furthermore, problem-based learning allows collaborative work and providing information processing theory (Bayat \& Tarmizi, 2012). Additionally, Sugeng and Suryani (2020) confirmed that adequate information is required to understand the problems, and it should go beyond what is provided in the problem description. Indeed, Hartman (2001) mentioned that procedural knowledge that is knowledge about how to apply learning procedures, for example, students are required to use strategies to find out the learning process. When applying processes in various situations, students can also gain knowledge through cooperative learning, and problemsolving.

In the third indicator, conditional knowledge showed an inevitable change during the cycles. Quantitatively, it was slightly higher than 60 percent and reached out at 74.6 percent in the next cycle. In this aspect, several students are likely inadequate to propose causal-comparative that is addressed to overcome the problems. In conditional knowledge, students are suggested to apply learning strategies depending on the environment. In this study, the increasing conditional knowledge of students is affected by their ability to choose an appropriate strategy in solving given problems in the supply and demand topic. Moreover, students have to understand the facts and concepts related to economics topics using relevant strategies. For example, when students attempted proposing an idea to solve the given problem, they need to collect information first, then analyzing and presenting their arguments. In addition, this study supports previous studies by Sastrawati et al. (2011); Narmaditya et al. (2018); Mulyanto, Gunarhadi, and Indriayu, (2018) which mentioned that there is a relationship between problem-based learning and students' thinking skills, particularly in addressing given problems in the particular topic.

On the other hand, planning included the three least indicators of students' awareness. This finding implies that students' ability to propose planning was categorized as a moderate level. The planning indicators indicate that before starting learning with the model applied, students already have awareness in planning the learning process, where planning indicators are felt important before students begin learning. However, during the research, students were difficult to encourage their basic knowledge about the topic needed in solving the given problem in supply and demand. The inadequate knowledge leads to the students' ability to overcome the problem using a particular strategy.

This finding confirms prior work by Jagals (2016) which remarked that in planning deals with expectations and predictions that occur before problem-solving begins by choosing certain knowledge strategies, while monitoring carried out during the learning process refers to personal understanding by checking whether the conditions of the problem reflect prior knowledge and skills. Problem-based learning develops a greater thinking awareness of what they know and unknown, further, it helps students to provide a plan, understand the progress, analysis and evaluate by themselves to change their behaviour and learning strategies. Similarly, this finding agrees with previous research by Haryani et al. (2017); Choi (2004), which stated that problem-based learning significantly affects metacognitive awareness in planning.

The next indicator is the informational management strategies. The finding showed an upward movement from level 59.6 to 69.7 percent at the end of the cycle. It implies that students have moderately action in receiving valuable information, focuses attention on critical information and new information. Furthermore, students insufficient in proposing their example related to supply and demand, having the ability to draw diagram and movement demand and supply curve and adequate in using organization structure for the given topic. In this case, problem-based learning suffers a gradual movement toward informational management strategy.

Another three knowledge, including monitoring, debugging strategy, and evaluation, showed different changes. Monitoring experienced about ten percent during cycles while debugging strategy and evaluation had risen less than eight percent. It was shown by students' activities in considering several alternative choices related to supply and demand before proposing ideas and answers. Moreover, periodically learners review the topic in order to comprehensively understand the phenomenon in supply and demand. They succeeded in analyzing by themselves usefulness and appropriate strategy to solve problems in economics subject. The debugging strategy of students showed a slight movement during the period. It means that students rarely change their strategies when they failed in solving given problems. The students' behavior also showed that they often discontinued reading when they do not become aware of new information. Lastly, students are able to make a self-evaluation related to how well students accomplished their goals.

Based on those explanations, it could be concluded that problem-based learning has successfully led to greater metacognitive awareness. It remarked that students should participate actively in their learning process and able to choose their strategy. Their experiences from their discoveries are likely more natural to be remembered rather than any information they obtained from direct instructions. Indeed, these findings agree with previous studies by Danial (2010); Turan et al. (2009); Herlanti et al. (2017), which mentioned a robust correlation between problem-based learning and metacognitive awareness.

\section{Conclusion}

This study attempts to comprehensively understand the implementation of problem-based learning toward students' metacognitive awareness which conducted in two cycles. The 
findings of the study showed remarkable changes between cycles. More precisely, the higher movement was in conditional knowledge followed by declarative and procedural knowledge, respectively. Meanwhile, the debugging strategy was the lowest variable that experienced movement during the cycles. Therefore, it can be concluded that problem-based learning encounters students to have a greater level of metacognitive awareness in economics subject due to problem-based learning allows students to participate actively in their learning process and able to choose their own strategy. Their experiences from own discoveries are likely easier to be remembered instead of any information they obtained from direct instructions. The influence of problem-based learning on students' metacognitive awareness in the economics course, is based on learning steps that actively involve students to solve the problem at hand. As for giving problems, encouraging problem solving, and collaborative interactions that are raised during learning between students and teachers, will facilitate learner to develop their metacognitive awareness.

\section{Suggestion}

For further researchers are expected to apply variations of the model as and on subjects whose concepts relate to daily life and can increase students' metacognitive awareness

\section{LIMITATION}

Since the research was conducted using technological information such as Zoom, it is difficult to manage one by one students' activities related to given problem to be discussed in this study. Also, the group involvement among group of learners seems insufficient to show their collaboration.

\section{References}

Abdellah, R. (2015). Metacognitive Awareness and Its Relation to Academic Achievement and Teaching Performance of PreService Female Teacher in Ajman University in UEA. Procedia - Social and Behavioral Sciences, 174, 560-567. https://doi. org/10.1016/j.sbspro.2015.01.707

Al-Awdah, D., Jasmeen, S., \& Alexander, A. (2017). A quantitative evaluation of metacognitive awareness among business administration students. Archives of Business Research, 5(1), 16-25. https://doi.org/10.14738/abr.51.2565

Anderson, N. J. (2012). Metacognition: Awareness of language learning. In Psychology for language learning (pp. 169-187). Palgrave Macmillan, London.

Anderson, O. W., \& Krathwohl, D. R. (2001). A Taxonomy for Learning, Teaching, and Assessing (A Revision of Bloom's Taxonomy of Educational Objectives). New York: Addision Wesley Longman, Inc.

Arifin, A. N., \& Saenab, S. (2014). Perbandingan Kesadaran Metekognitif Siswa yang diajar Menggunakan Model Problembased Instruction (PBI) dengan Kooperatif Tipe Think Pair Share (TPS). Bionature, 15(2), 81-89. https://doi.org/10.35580/ bionature.v15i2.1552
Asy'ari, M., \& Ikhsan, M. (2019). The Effectiveness of Inquiry Learning Model in Improving Prospective Teachers' Metacognition Knowledge and Metacognition Awareness. International Journal of Instruction, 12(2), 455-470. https:// doi.org/10.29333/iji.2019.12229a

Atmatzidou, S., Demetriadis, S., \& Nika, P. (2018). How does the degree of guidance support students' metacognitive and problem solving skills in educational robotics?. Journal of Science Education and Technology, 27(1), 70-85. https://oi. org/10.1007/s10956-017-9709-x

Bahri, A., \& Corebima, A. D. (2019). Improving PBL in Empowering Meta cognitive Skill of Students. Indian Journal of Science and Technology, 12(17), 1-9.

Bayat, S., \& Tarmizi, R. A. (2012). Effects of Problem Based Learning Approach on Cognitive Variables of University Students. Procedia-Social and Behavioral Sciences, 46, 3146-3151. https:// doi.org/10.1016/j.sbspro.2012.06.027

Bogdanović, I., Obadović, D. Ž., Cvjetićanin, S., Segedinac, M., \& Budić, S. (2017). Students' Metacognitive Awareness and Physics Learning Efficiency and Correlation Between Them. European Journal of Physics Education, 6(2), 18-30.

Ceker, E., \& Ozdamli, F. (2016). Features and Characteristics of Problem Based Learning. Cypriot Journal of Educational Sciences, 11(4), 195-202.

Choi, H. (2004). The effects of PBL (Problem-Based Learning) on the metacognition, critical thinking, and problem solving process of nursing students. Journal of Korean Academy of Nursing, 34(5), 712-721. https://dx.doi.org 10.4040/jkan.2004.34.5.712

Coutinho, S. A. (2007). The Relationship Between Goals, Metacognition, and Academic Success. Educate, 7(1), 39-47.

Danial, M. (2010). Kesadaran Metakognisi, Ketrampilan Metakognisi dan Penugasan Konsep Kimia Dasar. Jurnal Ilmu Pendidikan, 17(3), 225-229. http://dx.doi.org/10.17977/ jip.v17i3.2722

Dardjito, H. (2019). Students' Metacognitive Reading Awareness and Academic English Reading Comprehension in EFL Context. International Journal of Instruction, 12(4), 611-624. https://oi. org/10.29333/iji.2019.12439a

Delahaij, R., \& van Dam, K. (2016). Coping style development: The role of learning goal orientation and metacognitive awareness. Personality and Individual Differences, 92, 57-62. https://doi. org/10.1016/j.paid.2015.12.012

Efrilla, G., Amnah, S., \& Suryanti, E. (2018). Profil Kesadaran dan Strategi Metakognisi Siswa SMP Negeri Se-Kecamatan Lempar. Journal of Natural Science and Integration, 1(1), 69-77.

Farahian, M., \& Avarzamani, F. (2018). The Impact of Portfolio on EFL Learner's Metacognition and Writing Performance. Congent Education, 5(1), 1-21. https://doi.org/10.1080/23311 86X.2018.1450918

Flavell, J. H. (1976). Metacognitive Aspects of Problem Solving. In L. B. Resnick (Ed.), The nature of intelligence (pp. 231-235). Hillsdale, NJ: Lawrence Erlbaum.

Fritzsche, E. S., Händel, M., \& Kröner, S. (2018). What do secondorder judgments tell us about low-performing students' metacognitive awareness?. Metacognition and Learning, 13(2), 159-177.

Gholami, M., Moghadam, P. K., Mohammadipoor, F., Tarahi, M. J., Sak, M., Toulabi, T., \& Pour, A. H. H. (2016). Comparing 
the Effects of Problem-Based Learning and the Traditional Lecture Method on Critical Thinking Skills and Metacognitive Awareness in Nursing Students in a Critical Care Nursing Course. Nurse Education Today, 45, 16-21. https://doi. org/10.1016/j.nedt.2016.06.007

Hadiyanti, R. (2018, March). Analysis of mathematical problemsolving ability based on metacognition on problem-based learning. In Journal of Physics: Conference Series (Vol. 983, No. 1, p. 012157). IOP Publishing.

Harrison, G. M., \& Vallin, L. M. (2018). Evaluating the metacognitive awareness inventory using empirical factor-structure evidence. Metacognition and Learning, 13(1), 15-38. https:// doi.org/10.1007/s11409-017-9176-z

Hartman, H. J. (2001). Developing Students' Metacognitive Knowledge and Skills. In Metacognition in Learning and Instruction (pp. 33-68). Springer, Dordrecht.

Haryani, S., Masfufah., Wijayati, N., \& Kurniawan, C. (2017). Improvement of Metacognitive Skills and Students' Reasoning Through Problem-Based Learning. IOP Conf. Series: Journal of Physics: Conf. Series, 983, 012174. https://doi.org/10.1088/17426596/983/1/012174

Herlanti, Y., Mardiati, Y., Wahyuningtyas, R., Mahardini, E., Iqbal, M., \& Sofyan, A. (2017). Discovering Learning Strategy to Increase Metacognitive Knowledge on Biology Learning in Secondary School. Jurnal Pendidikan IPA Indonesia, 6(1), 179186. https://doi.org/10.15294/jpii.v6i1.9605

Heswandi, H., Muhali, M., \& Raehanah, R. (2015). Pengaruh model contextual teaching and learning terhadap kesadaran metakognisi dan hasil belajar siswa pada materi larutan penyangga. Hydrogen: Jurnal Kependidikan Kimia, 3(1), 221227.

Hidayat, R., Zulnaidi, H., \& Zamri, S. N. A. S. (2018). Roles of Metacognition and Achievement Goals in Mathematical Modeling Competency: A Structural Equation Modeling Analysis. PloS one, 13(11), e0206211. https://doi.org/10.1371/ journal.pone.0206211

Jaleel, S., \& Premachandran, P. (2016). A Study on the Metacognitive Awareness of Secondary School Students. Universal Journal of Educational Research, 4(1), 165-172. https://doi.org/10.13189/ ujer.2016.040121

Joseph, N. (2009). Metacognition needed: Teaching middle and high school students to develop strategic learning skills. Preventing School Failure: Alternative Education for Children and Youth, 54(2), 99-103.

Keegan, L. C., Losardo, A., \& McCullough, K. C. (2017). Problembased learning and civic engagement in undergraduate education. Communication Disorders Quarterly, 39(1), 312-319.

Kesici, S., Erdogan, A., \& Özteke, H. I. (2011). Are the Dimensions of Metacognitive Awareness Differing in Prediction of Mathematics and Geometry Achievement?. Procedia-Social and Behavioral Sciences, 15, 2658-2662.

Klegeris, A., \& Hurren, H. (2011). Impact of problem-based learning in a large classroom setting: student perception and problemsolving skills. Adv. Physiol Educ, 35, 408-415. https://doi. org/10.1152/advan.00046.2011.

Mirici, I. H. (2019). An Erasmus+ project on the use of the EPOSTL by student teachers of English. The Journal of Language Teaching and Learning, 9(1), 101-114.
Muhlisin, A., Susilo, H., Amin, M., \& Rohman, F. (2018). The Effectiveness of RMS Learning Model in Improving Metacognitive Skills on Science Basic Concepts. Journal Turkish Science. Education, 15(4), 1-14. https://doi.org/10.12973/ tused.10242a)

Mulyanto, H., Gunarhadi, G., \& Indriayu, M. (2018). The effect of problem based learning model on student mathematics learning outcomes viewed from critical thinking skills. International Journal of Educational Research Review, 3(2), 37-45. https://doi.org/10.24331/ijere.408454

Narmaditya, B. S., Wulandari, D., \& Sakarji, S. R. B. (2018). Does Problem-Based Learning Improve Critical Thinking Skill?. Cakrawala Pendidikan, 37(3) 378-388. https://doi.org/10.21831/ cp.v38i3.21548

Nurajizah, U., Windyariani, S., \& Setiono. (2018). Improving Students' Metacognitive Awareness Through Implementing Learning Journal. International Journal of Biology Education, 4(2), 105-112. https://doi.org/10.22219/jpbi.v4i2.5788

Pantiwati, Y., \& Husamah, H. (2017). Self and peer assessments in active learning model to increase metacognitive awareness and cognitive abilities. Self and Peer Assessments in Active Learning Model to Increase Metacognitive Awareness and Cognitive Abilities. International Journal of Instruction, 10(4), 45-57. https://doi.org/10.12973/iji.2017.10411a

Papleontiou-Louca, E. (2003). The concept and instruction of metacognition. Teacher Development, 7(1), 9-30. https://doi. org/10.1080/13664530300200184

Phungsuk, R., Viriyavejakul, C., \& Ratanaolarn, T. (2017). Development of a problem-based learning model via a virtual learning environment. Kasetsart Journal of Social Sciences, 38(3), 297-306.

Pradjono., \& Wardaya, (2009). Peningkatkan Kemampuan Analisis, Sintesis, dan Evaluasi melalui Pembelajaran Problem Solving. Cakrawala Pendidikan, 27(3), 257-269. https://doi.org/10.21831/ cp.v3i3.303

Ridley, D. S., Schutz, P. A., Glanz, R. S., \& Weinstein, C. E. (1992). Selfregulated learning: The interactive Influence of Metacognitive Awareness and Goal-setting. The Journal of Experimental Education, 60(4), 293-306. https://doi.org/10.1080/00220973. 1992.9943867

Sastrawati, E., Rusdi, M., \& Syamsurizal. (2011). Problem-Based Learning, Strategi Metakognisi dan Ketrampilan Berpikir Tingkat Tinggi Siswa. Tekno-Pedagogi, 1(2),1-14.

Scraw, G., \& Moshman, D. (1995). Metacognitive Theories. Educational Physchology Papers and Publications Paper 40. Retrieved from https://digitalcommons.unl.edu/edpsychpapers/40

Shahbari, J. A., Daher, W., \& Rasslan, S. (2014). Mathematical Knowledge and the Cognitive and Metacognitive Processes Emerged in Model-eliciting Activities. International Journal on New Trends in Education and Their Implications, 5(2), 209-219.

Siagan, M. V., Saragih, S., \& Sinaga, B. (2019). Development of Learning Materials Oriented on Problem-Based Learning Model to Improve Students' Mathematical Problem-Solving Ability and Metacognition Ability. International electronic journal of mathematics education, 14(2), 331-340.

Sugeng, B., \& Suryani, A. W. (2020). Enhancing the learning performance of passive learners in a Financial Management class using Problem-Based Learning. Journal of University Teaching \& Learning Practice, 17(1), 5. 
Sugiman, S., Retnowati, E., Ayres, P., \& Murdanu, M. (2019). Learning goal-free problems: collaboratively or individually?. Jurnal Cakrawala Pendidikan, 38(3), 590-600. https://dx.doi. org/10.21831/cp.v38i3.26914

Surif, J., Ibrahim, N. H., \& Mokhtar, M. (2012). Conceptual and Procedural Knowledge in Problem Solving. Procedia-Social and Behavioral Sciences, 52, 416-425.

Thayeb, T., \& Putri, A. P. (2017). Kemampuan Metakognisi Untuk Meningkatkan Ketrampilan Pemecahan Masalah Matematika Siswa Kelas VIIB MTS Madani Alauddin Paopao Kabupaten Gowa. Mapan: Jurnal Matematika dan Pembelajaran, 5(1), 1-17.

Tibrani, M. M. (2017). Metacognitive Awarness of Biology Education Students in Human Physiology Lecture. Jurnal Pembelajaran Sains, 1(1), 19-23. http://dx.doi.org/10.17977/um033v1i1 p19-23

Tosun, C., \& Senocak, E. (2013). The Effects of Problem-Based Learning on Metacognitive Awareness and Attitudes toward Chemistry of Prospective Teachers with Different Academic Backgrounds. Australian Journal of Teacher Education, 38(3), 61-73. https://dx.doi.org/10.14221/ajte.2013v38n3.2

Turan, S., Demirel, O., \& Sayek, I. (2009). Metacognitive Awareness and Self-Regulated Learning Skills of Medical Students in Different Medical Curricula. Medical Teacher, 31(10), 477-483. https://dx.doi.org/10.3109/01421590903193521.
Wang, Y., \& Treffers-Daller, J. (2017). Explaining listening comprehension among L2 learners of English: The contribution of general language proficiency, vocabulary knowledge and metacognitive awareness. System, 65, 139-150. https://doi. org/10.1016/j.system.2016.12.013

Wibowo, L. A., Sihaloho, L., \& Rahayu, A. (2018). The Role of Self Efficacy in Improving Student Metacognitive Skills. JPBM: Jurnal Pendidikan Bisnis dan Manajemen, 4(3), 119-127.

Wolfe, M. B., \& Williams, T. J. (2018). Poor Metacognitive Awareness of Belief Change. Quarterly Journal of Experimental Physcology, 71(9), 1898-1909. https://dx.doi.org/10.1080/17470218.2017.1 363792

Wulandari, D., \& Narmaditya, B. S. (2017). Readers Theater as a Tool to Understand Difficult Concept in Economics. International Education Studies, 10(5), 144-156. https://dx.doi.org/10.5539/ ies.v10n5p144.

Young, A., \& Fry, J. D. (2008). Metacognitive awareness and academic achievement in college students. Journal of the Scholarship of Teaching and Learning, 8(2), 1-10.

Yuan, K., Aftoni, A., \& Çobanoğlu, Ö. (2020). The Effect of ProblemBased Learning Model and Blended Learning Model to Metacognitive Awareness as a Reflection Towards a New Normal Era. Jurnal Pendidikan Teknologi dan Kejuruan, 26(2), 183-188. 